\title{
RESTRICTIVE DEVELOPMENTS IN THE LAW OF MILITARY SEARCH AND SEIZURE
}

ThE AUTHORITY of a commanding officer to inspect and search per-
sonnel or property within his command has long been considered indis-
pensable to the maintenance of order and discipline. ${ }^{1}$ In deference to his
extraordinary responsibility, ${ }^{2}$ he must be entrusted with broader search
powers than would be tolerated in a civilian government. ${ }^{3}$ The absence
of any military equivalent to the civilian search warrant has, in fact, been
cited in support of the contention that the commanding officer's discre-
tion to order a search within his command cannot be questioned..$^{4}$
Yet, provision is made for a concept of unlawful search which
serves to restrict the power of military authorities. Paragraph I 52 of
the Manual for Courts-Martial ${ }^{5}$ provides that, "Evidence is inadmis-

${ }^{1}$ A.C.M. 6I72, Turks, 9 C.M.R. 64 I (1952), citing United States v. Florence, I U.S.C.M.A. 620, 5 C.M.R. 48 (1952). In A.C.M. 4023, Arteaga, I C.M.R. 632, 635 (195I), the court stated: "Such searches have been made pursuant to military command as distinguished from civil warrant ever since the foundation of this government." C.M. 248379, Wilson, 31 Bd. Rev. 23 I, 235 (I944); A.C.M. II793, Dutcher, 21 C.M.R. 747, 750, aff'd, United States v. Dutcher, 7 U.S.C.M.A. 439, 22 C.M.R. 229 (1956); C.M. 335526 , Tooze, 3 Bd. Rev.-Jud. Council 3I3, 346 (1949); A.C.M. 1458, Worley, 3 C.M.R. (AF) 424 (1950); Digest OF OPINIONS OF T'́ne Judge ADVOCATE GENERAL OF THE ARMY, 250.413, §395(27) 220, (1912-40), cited with approval in Richardson v. Zuppann, 8 I F. Supp. 809 (M.D. Pa.), aff'd per curiam, I74 F.2d 829 (3d Cir, 1949).

2A.C.M. II753, Walsh, 2 I C.M.R. 876 (1955); United States v. Rhodes, 3 U.S.C.M.A. 73, II C.M.R. 73 (1953).

${ }^{3}$ Gillars v. United States, I8z F.2d 962 (D.C. Cir. 1950); Romero v. Squier, 133 F.2d 528 (9th Cir. 1943), cert. denied, 3 I 8 U.S. 785 (1943); Richardson v. Zuppann, 8I F. Supp. 809 (M.D. Pa. 1949). See also, In $r e$ Meader, 60 F. Supp. 80 (E.D.N.Y. I945).

4A.C.M. 11793 , Dutcher, 2 I C.M.R. 747 (1956). See also Richardson v. Zuppann, stipra note 3. The suggestion has also been advanced that the commanding officer has a proprietary interest in the land where his troops are stationed-an interest similar to that of the landowner-and thus has absolute authority to order a search on the premises. Everett, Military JUstice in the ARMed Forces of the UNited States 102 (1956).

The Uniform Code of Military Justice was enacted by Congress on May 5, I950. 64 Stat. 108 (1950), 50 U.S.C. $\$ \$ 551-741$ (1952) (now 1o U.S.C. $\$ \S 801-940$ (1958)). Pursuant to article 36 of the UCMJ, President Truman, by Executive Order 10214 of February 8, 1951, ordered publication of the Manual for Courts-Martial, prescribing rules of evidence and procedure for military courts-martial. U.S. DEP'r of Defense, Manual for Courts-Martial United States (I951) [hereinafter cited as MCM]. In United States v. Sonnenschein, I U.S.C.M.A. 64, 67, I C.M.R. 64, 67 
sible against the accused if it was obtained as a result of an unlawful search of his property conducted or instigated by persons acting under authority of the United States. ..." Therefore, while there is no affirmative prohibition in either the Manual for Courts-Martial or the Uniform Code of Military Justice against unreasonable search and seizure, ${ }^{7}$ nevertheless, the basic inquiry in applying the exclusionary rule of evidence is whether the search in question was in fact unreasonable. ${ }^{8}$

(1951), the Court of Military Appeals, adopting United States v. Lucas, I U.S.C.M.A. 19, I C.M.R. I9 (1951), stated that the Uniform Code of Military Justice and the act of the Manual for Courts-Martial) are "regarded as sharing a similar authoritative position."

'The doctrine of exclusion is derived from Weeks v. United States, 232 U.S. $3_{3}{ }_{3}$ (1974). Its first expression in military law may be found in 3 BULLETIN OF THE JUDGE AdVOCATE General of THE ARMY $\$ 395$ (27), at 512 (1944); 7 id. at 75 (1948). Sec also; N.C.M. 58-001 30, Hillan, 26 C.M.R. 771 (1958); United States v. Volante, 4 U.S.C.M.A. 689, 16 C.M.R. 263 (1954); United States v. Wilcher, 4 U.S.C.M.A. 215, 15 C.M.R. 215 (1954); Mee, Search and Seizure, NAvY JAG J., Mar., 1948, p. 2; $i d$., April, r 948, p. 8.

The term "unlawful" must be interpreted in light of the constitutional prohibition of unreasonable searches. Carroll v. United States, 267 U.S. 132 (1925).

"For a discussion of this matter, see Cobbs \& Warren, Military Searches and Seizurts, MilitaRy L. Rev. I (Dep't of Army Pamphlet No. 27-100-1, 1958).

${ }^{8}$ Go-Bart Importing Co. v. United States, 282 U.S. 344 (1931); Matthews v. Correa, 135 F.2d 534 (2d Cir. 1943). See also United States v. Rhodes, 3 U.S.C.M.A. 73, Ix C.M.R. 73 (1953); United States v. Doyle, I U.S.C.M.A. 545, 4 C.M.R. 137 ( 1952 ). Evidence obtained by unreasonable searches may not be properly admitted before a military tribunal. Ibid.; United States v. Ball, 8 U.S.C.M.A. 25,23 C.M.R. 249 (1957). A search, if illegal at its inception, cannot be justified by what it reveals. Navy Dep't Court-Martial Order No. 12-1949, 302 (Dec. 1949); N.C.M. 58-00130, Hillan, 26 C.M.R. 771 (1958); United States v. Ball, 8 U.S.C.M.A. 25, 23 C.M.R. 249 (1957). See United States v. Di Re, 332 U.S. 581 (1947).

At common law, the court was concerned with the trustworthiness of evidence, not whether it had been illegally obtained. Everett, New Procedures of Scientific Investigation and the Protection of the Accused's Rights, 1959 DUKE L.J. 32, 35. See also, Wolf. v. Colorado, 338 U.S. 25 (1949). In the military as well as in the federal courts, there is no relation to the trustworthiness of the evidence. United States v. Dupree, 1 U.S.C.M.A. 665,5 C.M.R. 93 (1952).

The military court martial has no power to suppress illegally obtained evidence. However, such evidence will be excluded provided that the accused has raised a timely objection thereto. Legal and Legislative Basis, Manual for Courts-Martial, UnITED States 240 (195I). See also, Cobbs \& Warren, supra note 7, at 18 . Ordinarily, failure of the accused to object at the trial to the admission of evidence obtained as a result of an illegal search or seizure results in a waiver of the objection, and he is thereafter precluded from asserting this contention on appeal. United States v. Webb, 1o U.S.C.M.A. 442, 27 C.M.R. 496 (1959); United States v. Fischer, 4 U.S.C. M.A. 152, 5 C.M.R. 152 (1954); United States v. Dupree, supra.

Thus, the mere admission of illegally obtained evidence will not of itself constitute reversible error. If the accused has not waived objection, the record of the trial will be examined by reviewing authorities to ascertain whether the accused has been prejudiced 
Paragraph I 52 of the Manual sets forth specific illustrations of a lawful search. ${ }^{9}$ Briefly, it states that searches are lawful when conducted: (I) under a warrant issued by a court; (2) incident to a lawful apprehension ${ }^{10}$ (the military equivalent of arrest); (3) under circumstances demanding immediate action to prevent removal of "criminal goods"; ${ }^{11}$ and (4) with the accused's consent. ${ }^{12}$ The Manual goes on to state as a fifth category of lawful search: ${ }^{.13}$

... A search of property which is owned or controlled by the United States and is under the control of an armed force, or of property which is located within a military installation or in a foreign country or in occupied territory and is owned, used, or occupied by persons subject to military law or to the law of war, which search has been authorized by a commanding officer (including an officer in charge) having jurisdiction over the place where the property is situated or, if the property is in a foreign country or in occupied territory, over personnel subject to military law or to the law of war in the place where the property is situated. The commanding officer may delegate. the general authority to order searches to persons of his command.

Paragraph I 52 concludes with a sentence which, because it is in the same paragraph, appears to modify the fifth category of lawful search:

This example of authorized searches is not intended to preclude the legality of searches made by military personnel in the areas outlined above when made in accordance with military custom.

Recent decisions of the Court of Military Appeals interpreting paragraph I 52 and involving situations upon which the two passages quoted

by the admission of such evidence. Agnello v. United States, 269 U.S. 20 (1925); United States v. Higgins, 6 U.S.C.M.A. 308, 20 C.M.R. 24 (1955).

- The Manual for Courts-Martial enumerates five situations in which a search may be deemed lawful. MCM I $\mathbf{1 5}_{2}$. Except for the final category, relating to a military search, these illustrations may be found in a table of cases relating to searches in Harris v. United States, 33 I U.S. 145, 175-81 (1947).

${ }^{10}$ Evidence obtained by a search made as an incident to a lawful arrest is not illegally obtained, and is thus admissible. United States v. Florence, I U.S.C.M.A. 620, 5 C.M.R. 48 (1952); United States v. Rabinowitz, 339 U.S. 56 (1950); Harris v. United States, 33I U.S. I45 ( 1947 ). See EVERETT, op. cit. supra note 4, at 99.

${ }^{11}$ See note 15 infra.

${ }_{13}$ Mere submission to authority does not constitute consent. United States v. French, 1o U.S.C.M.A. 171, 27 C.M.R. 245 (1959); United States v. Wilcher, 4 U.S.C.M.A. 215,15 C.M.R. 215 (1954).

${ }_{13}$ The fifth category of lawful searches was carried over to the present Manual from a similar example in paragraph 138 of the 1949 Manual. The legality of searches of this nature has been upheld in Best v. United States, 184 F.2d 13I (1st Cir. 1950), cert. denied, 340 U.S. 939 (195I); Grewe v. France, 75 F. Supp. 433, 437 (E.D. Wis. 1948). 
above have some bearing, seem to have imposed restrictions upon the search powers of commanding officers heretofore unknown to military law.

The Search Made in Accordance with Military Custom

In the fifth category of lawful searches quoted above, the Manual for Courts-Martial makes specific provision for the legality of searches authorized or conducted by a commanding officer, either of property owned or controlled by the United States and under the control of an armed service, or of property located within a military installation and owned or used by military personnel. Search of the person is expressly authorized only in connection with apprehension ${ }^{14}$ or the prevention of removal or disposal of property reasonably believed to be criminal goods. ${ }^{15}$ Traditionally, however, search of the person has been upheld as lawful when conducted "in accordance with military custom."10 Since neither the Manual nor the courts have clearly delineated the search made in accordance with the custom of the service, its precise scope is undetermined. ${ }^{17}$

${ }^{16}$ MCM I I52. The same rule obtains in the federal courts. United States v. Rabinowitz, 339 U.S. 56, 60 (1950); Weeks v. United States, 232 U.S. 383,392 (1914).

${ }^{15} \mathrm{MCM}$ I 152. This rule is derived from earlier federal cases involving violations of the National Prohibition Act, ch. 85, \& I, 41 Stat. 305 (1919). Since it became impractical to require federal officers to procure warrants prior to the seizure of whiskey being illegally transported by motor vehicle, searches conducted under such circumstances were deemed "reasonable." Brinegar v. United States, 338 U.S. I60 (I949) 3. Husty v. United States, 282 U.S. 694 (1931); Carroll v. United States, 267 U.S. 132. (1925). The application of this doctrine in military law has been extended beyond the search of automobiles, with the emphasis apparently on the disposability of the criminal goods rather than on inere mobility. United States v. Swanson, 3 U.S.C.M.A. 67I, 14 C.M.R. 89 (1954); United States v. Davis, 4 U.S.C.M.A. 577, I6 C.M.R. 15 I (I954).

${ }^{10}$ See I Bulletin of the Judge Advocate General of the ARMY 2 (1942); 7 id. at 75 (1948); MCM I 152. In A.C.M. 435 I, Gosnell, 3 C.M.R. 646, 658 (1952), the Air Force Board of Review recognized that, "Traditionally, even before the 1949 and 195 I Manuals for Courts-Martial set forth rules regarding searches and seizures, the military service, by custom, had accepted as legal searches on military installations when authorized by commanding offcers." A search made in accordance with military custom does not require authority of the commanding officer. United States v. Rhodes, 3 U.S.C.M.A. 73, I I C.M.R. 73 (1953); United States v. Doyle, I U.S.C.M.A. 545, 4 C.M.R. 137 (1952). However, general exploratory searches, so conducted, are illegal. C.M. 354597, Thomas, 6 C.M.R. 259 (1952); C.M. 354571, LaMothe, 6 C.M.R. 257 (1952); C.M. 354324, Heck, 6 C.M.R. 223 (1952).

${ }^{17}$ In the Gosnell case, silpra note I6, the Air Force Board of Review stated that, "Although it is in connection with a breach of custom in violation of Article 134, the Manual for Courts-Martial, $195 \mathrm{I}$, in paragraph $213^{2}$ provides: 'In its legal sense the word 'custom' imports something more than a method or procedure or mode of conduct 
Originally, searches conducted "in accordance with military custom" were held to include only searches of a routine nature, those not intended to uncover evidence of a crime..$^{18}$ Under these circumstances, there was little justification for an analogy to searches pursuant to a civilian search warrant, which can be issued only by a proper tribunal upon a showing of probable cause. ${ }^{19}$ Gradually, the concept of the search made "in accordance with military custom" was extended to the situation wherein the express purpose of the search was to unearth evidence of a crime, and where it was directed to a specific individual.

In the leading case of United States $v$. Doyle, ${ }^{20}$ a search was conducted by a master-at-arms after he learned that stolen property had been discovered in the locker of the accused. The Court of Military Appeals held that the disciplinary representative of a commanding officer may, "on reasonable and probable cause," conduct a search of military property. Thus, the court noted that certain persons, by virtue of their duty and responsibility to enforce regulations, may possess inherent power to conduct searches on military premises regardless of any express delegation of authority by the commanding officer. The apparent justification for this lay within the doctrine of "military custom.”

A later case ${ }^{21}$ concerned the legality of a staff judge advocate's search of the desk of a claims officer in the command. His action was upheld

or behavior which is merely of frequent or usual occurrence. Custom arises out of long established practices which by common consent have attained the force of law in the military or other community affected by them. There can be no such thing as a custom that is contrary to existing law or regulations." " See WinTHROP, MiLitaRY LAW AND PRECEDENTS 42 (2d ed. 1920).

${ }^{18}$ E.g., searches conducted for overages of clothing or equipment, searches of vehicles leaving a command, periodic locker inspections, and numerons other practices which are essential to the discipline and well being of a military command. In A.C.M. 2900, Edwards, 3 C.M.R. (AF) 540, 543 (1950), the Board of Review noted that: "Barracks inspections and general 'shakedown' inspections which are not directed toward a specific person or his effects and not called for the pnrpose in particular of seeking to discover evidence of a crime, are routine formations. Therefore, evidence, turned up during such an inspection is not objectionable upon the ground that it was the subject of an unlawful search and seizure."

${ }^{10}$ In United States v. Brown, Io U.S.C.M.A. 482, 492, 28 C.M.R. $48,-(1959)$, Judge Latimer commented in a dissenting opinion that, " . . a commanding officer has the authority to conduct or order the search of the personnel or property under his command apart from any pre-existing apprehension and without the necessity of obtaining a search warrant. Such a search is clearly 'in accordance with military custom' ...." (Emphasis added.) See EvERETT, op. cit. supra note 4, at 103.

${ }_{20}$ I U.S.C.M.A. 545, 4 C.M.R. 137 (I952).

${ }^{21}$ United States v. Rhodes, 3 U.S.C.M.A. 73, Ix C.M.R. 73 (I953). 
on the ground that such searches may properly be effected by persons other than the commanding officer, if conducted according to wellestablished customs of the military.

Thus, from the earlier doctrine that a search conducted "in accordance with military custom" had to be of a general nature, and of the entire unit or command, the concept was apparently extended to include the search conducted by persons other than the commanding officer, even though it was directed toward a particular individual and was for the specific purpose of discovering evidence of a crime.

In the case of United States $v$. Brown, ${ }^{22}$ the Court of Military Appeals, in the majority opinion, completely ignored "the search in accordance with military custom," and held unlawful a search which arguably fell within that phrase as interpreted in prior decisions. In that case, the accused and nine other soldiers were suspected of using narcotics. The commanding officer ordered that they be apprehended and searched. A sergeant, who conducted the search under the commanding officer?s direction, discovered two bottles of heroin on the person of the accused. The court, purporting to consider all of the lawful-search situations set forth in the Manual, stated that the fifth category was "clearly inapplicable here ...., the search having been of the person rather than of property. "233 Having supposedly exhausted the five general types of lawful searches, the court concluded that the bottles of heroin were the product of an illegal search and, hence, that they were inadmissible as evidence.

As Judge Latimer pointed out in his dissent, ${ }^{24}$ however, the majority, in quoting the general search clause of the Manual, omitted the concluding sentence of the final category of lawful searches, which provides that: ${ }^{25}$

... This example of authorized searches is not intended to preclude the legality of searches made by military personnel in the areas outlined above when made in accordance with military custom.

Could not the Brown search have been brought within the concept of "searches in accordance with military custom"? In view of the dis-

${ }^{22}$ 10 U.S.C.M.A. 482,28 C.M.R. $48,-(1959)$.

${ }^{23} I d$. at 488,28 C.M.R. at -.

${ }^{24}$ Id. at 490,28 C.M.R. at -.

${ }^{25}$ MCM I152. (Emphasis added.) As stated in A.C.M. 11793 , Dutcher, 21 C.M.R. 747,750 (1956), "[I] t appears that an appropriate commanding officer has the inherent authority to search the person of a member of his command. Clearly, this authority may be exercised by the commanding officer by ordering the member of his command into his presence for the purpose of conducting a search of the suspect's person." 
senter's lengthy opinion, it seems indefensible for the majority. not only to have omitted comment on this possibility, but also to have excluded the crucial sentence from a purportedly exhaustive quotation of the categories of legal searches provided in the Manual.

If, indeed, the Court of Military Appeals even recognizes the existence of a search "in accordance with military custom," authorization for such a search must lie in the very sentence of the Manual so deftly excised in the majority opinion. What is the significance of this deletion? Is the majority of the court now indicating that it will no longer sanction a search conducted in accordance with recognized custom of the service? Or are we now to assume that a search under the aegis of custom can only be performed of property and not of personnel? Heretofore, the commanding officer has had the power to search the person of a member of his command in accordance with military custom, the authority for such a search having been grounded on the sentence which was inexplicably omitted from the majority's quotation in the Brown case. $^{20}$ Excision of the provision for search "in accordance with military custom" from the Manual for Courts-Martial is, quite clearly, an indefensible example of judicial legislation.

\section{II}

\section{Probable Cause}

The Brown case has,also "created" law in another area. The Manual for Courts-Martial does not specifically require that the authority of the commanding officer to search personnel or property within the unit, be grounded upon probable cause. ${ }^{27}$ In the case of United States v. Doyle, ${ }^{28}$

${ }^{20}$ See Judge Latimer's dissenting opinion in Brown, supra note 19 , and cases cited therein. See also, Note, ror U. PA. L. Rev. 866 (I 953 ).

${ }^{27}$ MCM I152. See A.C.M. 11793 , Dutcher, 21 C.M.R. 747 (1956). In A.C.M. 6172, Turks, 9 C.M.R. 641, 647 (1952), the Board of Review declared: "The Manual for Courts-Martial, United States, I95I, does not affirmatively require that the commanding officer have a reasonable basis prior to authorizing a search within his command. In fact, we deem its silence in this regard highly significant. The Uniform Code of Military Justice is likewise completely silent in this regard. . . . Under general rules of statutory construction, the failure to add such a requirement can be interpreted as an expression of intent that the former military law in this regard should continue." The Board of Review cited Crawford, Construction of Statutes 184 (1940). See A.C.M. 4202, Barnes, 2 C.M.R. 797, 80r (r95 I).

It was recognized in Brinegar v. United States, 338 U.S. I60, I75-76 (1949), that the concept of probable cause is not readily reducible to a precise formula. In that case, the Court held that: "Probable cause exists where the facts and circumstances within their [the officers'] knowledge and of which they had reasonably trustworthy information [are] sufficient in themselves to warrant a man of reasonable caution in the belief 
however, the Court of Military Appeals, while recognizing that the commanding officer must possess powers commensurate with his responsibilities, cautioned, "That there may be limitations upon ... [this] power, we do not doubt." This dictum presaged a gradual trend in the court toward restricting the discretionary power of the commanding officer to initiate searches. ${ }^{20}$ Apparently, the climax of this development was reached in Brown, ${ }^{39}$ where the court sharply abridged the search powers of the commanding offcer by requiring that the exercise of his authority be grounded upon "probable cause."

In the Brown ${ }^{31}$ case, the court apparently regarded Doyle $e^{32}$ as authority for the proposition that the power of the commanding officer to search personnel or property within his jurisdiction is limited by the requirement of probable cause, stating that: ${ }^{33}$

While there is substantial discretion vested in the commanding officer to order a search of persons and property under his command, consideration of all the circumstances herein makes it clear beyond cavil that ... [the commanding officer] acted on nothing more than mere suspicion.

The Doyle case does not hold that a commanding officer may not act upon mere suspicion. On the contrary, the court in Doyle was concerned not with the search powers of the commanding officer, but rather, with the question of what limitations should be applied to one other

that an offense has been or is being committed." This case was cited in United States v. DeLeo, 5 U.S.C.M.A. 148, 158, 17 C.M.R. 148, 158 (1954). See also, United States v. Rabinowitz, 339 U.S. 56 (x950); Go-Bart Importing Co. v. United States, 282 U.S. 349 (I93I).

28 I U.S.C.M.A. 545, 548, 4 C.M.R. 137,140 (1952).

${ }^{28}$ In a subsequent decision, United States v. Florence, I U.S.C.M.A. 620, 623, 5 C.M.R. 48, 51 (1952), the Court of Military Appeals again straddled the fence on this issue, stating: "However, the Manual for Courts-Martial, United States, I95x, treats more fully with search and seizure and it may be the foundation for curtailing a commanding officer's powers. For that reason at this time we neither adopt nor reject the former rule because in this instance the commanding officer's conduct did not breach civilian principles." In A.C.M. 5796, Toreson, 8 C.M.R. 676, 682 n.2 (1953), the Board of Review noted the growing emphasis on this requirement, declaring that the Court of Military Appeals "has shown a preoccupation with 'probable cause' which suggests that evidence thereon would be relevant in many cases."

${ }^{30}$ United States v. Brown, ro U.S.C.M.A. 482, 28 C.M.R. 48 (1959).

${ }^{31}$ Ibid.

${ }^{32}$ United States v. Doyle, x U.S.C.M.A. 545, 4 C.M.R. 137 (1952).

${ }^{33}$ United States v. Brown, 1o U.S.C.M.A. 482, 488, 28 C.M.R. 48, - (1959). However, in his dissenting opinion in the same case, Judge Latimer states: "The word 'reasonable' as it must be interpreted in military law is not limitd to those situations where the commander has probable cause to believe a particular person possesses contraband and he alone can be searched." Id. at 492, 28 C.M.R.- 
than the commanding officer who, because of his official position, may have authority to order a search. The court, in dicta, merely alluded to the possibility that there may be limitations upon the commanding officer's search powers, but deferred consideration of any such restrictions on the ground that it was not confronted with such a question in that case. Indeed, the court clearly stated: ${ }^{34}$

In the absence of an express delegation, however, we hesitate to attribute to such a person [the disciplinary representative] the discretionary powers to search which are vested in the commanding officer. It is distinctly arguable that his power to search military property should be limited by a requirement that reasonable cause therefor be shown.

In view of this assertion that search powers of the disciplinary representative are to be restricted by the requirement of probable cause, and because the court differentiated him from the commander, it would seem-in accordance with the most fundamental rules of constructionthat the court impliedly excluded application of the probable-cause requirement to searches authorized by the commanding officer. Might it not be contended that the proper inference to be drawn from this language is that a commanding officer is not required to have probable cause, but that this requirement does devolve upon his disciplinary representative because it is thought unwise to vest the latter with powers equivalent to those of the commanding officer?

The Brown case went on to say that, while military officials may deviate somewhat from accepted civilian search procedures, the substantive rights of the individual-referring in this instance to the probable-cause requirement-remain the same as in civilian law. The court cited by footnote two cases $^{35}$ wherem searches conducted by federal narcotics agents were declared invalid because they were not founded upon probable cause. Although the question of the appropriateness of citing civilian authorities as precedent in military cases is discussed at greater length in a later section of this paper, suffice to say for the present that it is well-recognized that there is no precise parallel between civilian criminal law administration and the power of a military commander to direct searches within his organization. ${ }^{36}$

\footnotetext{
${ }^{86}$ I U.S.C.M.A. 545, 548, 4 C.M.R. 137, 140 (1952).

${ }^{35}$ United States v. Asendio, I I I F.2d 122 (3d Cir. I948); United States v. Reynolds, I I F F. Supp. 589 (D.D.C. 1953 ).

${ }^{80}$ The Judicial Council of the Air Force, in A.C.M. 1458, Worley, 3 C.M.R. (AF) 424, 442 (1950), pointed out: "The essential difference between military jurisdiction and civil jurisdiction is apparent. Under civil jurisdiction, the informant has no power alone to make a search. The officer who serves the process has no power in himself to
} 
The question of probable cause as related to a commander's authority to search was again considered, several months later, in United States v. Gebhart. ${ }^{37}$ There a company executive officer, having been informed of the theft of a camera, conducted an inconclusive "shakedown" inspection of the barracks. Later, the company police sergeant, "just out of curiosity," inspected the laundry bags in the barracks and detected a hard object in one bag. The sergeant notified the executive officer, who thereupon searched the bag and discovered the missing camera.

The Court of Military Appeals, while approving the propriety of the initial search, reasserted, by way of dicta, the doctrine of the Brown case, ${ }^{38}$ that is, that exercise of the authority to search must rest upon probable cause. The court again erroneously relied on Doyle 30 as authority.

\section{III}

\section{ThE "SHAKedown" InSPECTION}

In the Gebhart $t^{40}$ opinion, the court, citing United States v. Brown, ${ }^{41}$ stated that: ${ }^{42}$

Both the generalized and particularized types of searches are not to be confused with inspections of military personnel entering or leaving certain areas or those, for example, conducted by a commander in furtherance of the security of his command.

If this reasoning had in fact been applied in the Brown case, would the decision have been the same? As the dissenting opinion noted, the mili-

make a search. It requires the combined use of all three before a valid search and seizure can be made. On the other hand, the commanding officer with respect to property under his control has plenary power. He is fully and directly responsible to his government for all action necessary to perform his duties. He has the power of investigation to determine whether a search should be made and to execute a search or direct its execution. In other words, he has the power of Federal agents, the magistrate and the process server."

${ }^{37}$ 1 0 U.S.C.M.A. 606, 28 C.M.R. I72 (1959). Cf. United States v. Bolling, 10 U.S.C.M.A. 82,27 C.M.R. 156 (1958), where an orderly found an open duffie bag lying on the floor, which contained marijuana cigarettes. Agents from the Office of Special Investigations searched the bag. The court held that the search was reasonable.

${ }^{38}$ 1o U.S.C.M.A. $4^{82}, 28$ C.M.R. 48 (1 959). In Gebhart, Judge Ferguson, dissenting, argued that the fruits of the second search conducted by the Executive Officer were inadmissible since that search was made on the basis of information derived from a prior illegal search.

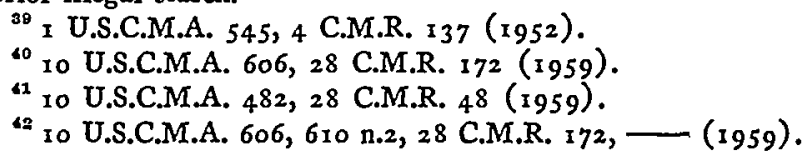


tary unit involved was stationed in South Korea; and, as a result of the illegal flow of narcotics from Communist China into the hands of American troops, the combat efficiency of the command was being steadily impaired. The accused had been on pass with several companions who were similarly suspected of using narcotics. Upon his return to the company area, he was searched on the suspicion of possessing narcotics. Was not this a search "of military personnel entering or leaving certain areas ... conducted in furtherance of the security of the command"? And would not the commanding officer have been derelict in his duty if he had failed to take effective measures to eliminate this insidious threat to the integrity of his command?

Assuming a less urgent fact situation than that of the Brown case, how is the commander to satisfy the probable cause requirement, with respect to a particular individual, when the customary "shakedown" inspection is deemed necessary?

The existence of such a concept as the "shakedown" inspection was acknowledged by Chief Judge Quinn in the Gebhart case, where, recognizing the propriety of the initial search conducted by the executive officer, he stated: "Armed with authority to conduct searches . . . Captain Reilly [the executive officer] proceeded to conduct the familiar 'shakedown' inspection of the effects of all personnel assigned to that room."43 Because Chief Judge Quinn used the terms "search" and "shakedown inspection" reciprocally, one might well infer that the latter concept embodies merely one type of search. Chief Judge Quinn goes on to say, however, that "this generalized type of search has long been regarded as reasonable, $" 44$ and he cites United States $v$. Swanson ${ }^{45}$ as authority for this proposition.

In Swanson, however, the court's conclusion that the search at issue was lawful was predicated upon a determination that immediate action had been necessary to prevent the removal of criminal goods. Authority for a search of this general type may be found in the third category listed in paragraph $\mathrm{I} 52$, which provides that a search is lawful if it is: $:^{46}$

${ }^{4}$ Id. at $6 \times 0,28$ C.M.R. at —.

4 Id. at 610,28 C.M.R. - .

${ }^{45} 3$ U.S.C.M.A. $67 x, x_{4}$ C.M.R. 89 (1954). In Swanson, the company first sergeant, upon being informed that a sum of money had been stolen, ordered a formation, in the absence of all unit officers, and conducted a "shakedown" inspection. See also, United States v. Davis, 4 U.S.C.M.A. 577, I6 C.M.R. I 5 (1954). Cf. A.C.M. 435 I, Gosnell, 3 C.M.R. 646 ( 1952 ) (search conducted by OOD held unlawful).

" MCM II 52. See Carroll v. United States, 267 U.S. 132 (1925). Cf. 2 Bulletin of the Judge Advocate General of the ARMY 264 (1943). 
... A search under circumstances demanding immediate action to prevent the removal or disposal of property believed on reasonable grounds to be criminal goods.

Thus, is Chief Judge Quinn saying in Gebhart that a generalized search is reasonable because the situation will invariably require "immediate action"? Is one to assume, then, that every "shakedown" inspection can be justified on this basis, or is it the proper inference that any such inspection must be justified on this ground in order to be legal? By reason of Gebhart's reliance on Swanson, it would seem that, so long as the commanding officer "has information that criminal goods can be found," $"{ }^{47}$ he is at liberty to authorize a general search within his command, on the ground that such action was necessary to prevent the immediate disposal of these goods.

Heretofore, it has generally been held that the words "under circumstances demanding immediate action to prevent the removal or disposal of property," are to be narrowly construed. ${ }^{48}$ Yet, can their application in the Swanson case itself be regarded as a narrow interpretation? On the contrary, it would appear that the court has stretched the application of this doctrine far beyond its intended limits. ${ }^{40}$

It is somewhat paradoxical that the court, whose zeal to protect the individual's right of privacy has led it to abridge sharply the commanding officer's authority to search, has, on the other hand, extended the concept of searches necessary to prevent the disposal of criminal goods far beyond the rule existing in the federal courts. And, yet, there is greater danger that an unreasonable search will be conducted in the latter situation, for admittedly a search of this type may be initiated by one other than the commanding officer-hence, by one less apt to exercise prudent judgment.

\section{IV}

\section{Rule of Procedure or Substantive Right?}

The real basis of the decisions in Brown ${ }^{50}$ and Gebhart, ${ }^{51}$ with respect to the probable-cause limitation on the commander's power to

\footnotetext{
${ }^{17}$ In United States v. Brown, ro U.S.C.M.A. 482,488 n.I, 28 C.M.R. $48,-$
} (1959), the court distinguished the case at bar from Swanson, on the ground that, contrary to that case, the commanding officer in Brown had no information that criminal goods could be found.

${ }^{48}$ A.C.M. 4351 , Gosnell, 3 C.M.R. 646 (1952); A.C.M. 4332, Kofnetka, 2 C.M.R. 773 (1952); A.C.M. 2330, Bundy, 2 C.M.R. (AF) 809 (x950).

${ }^{10} \mathrm{See}$ Cobbs \& Warren, supra note 7 .

${ }^{50}$ 10 U.S.C.M.A: 482, 28 C.M.R. 48 (1959).

${ }_{11} 10$ U.S.C.M.A. 606, 28 C.M.R. 172 (1959). 
search, was the court's desire to afford servicemen the basic rights and privileges accorded civilians by the Constitution. This was manifested by the statement in the latter case that: ${ }^{52}$

To hold otherwise would require us to deny to military personnel the full protections of the United States Constitution itself. This, neither we, nor the Congress, nor the Executive, nor any individual can do.

The question of the application of constitutional guarantees to military personnel ${ }^{53}$ has continually plagued the federal courts ${ }^{54}$ and military tribunals. ${ }^{55}$ The Court of Military Appeals has repeatedly stressed

52 Id. at 6ro, 28 C.M.R. at -.

${ }^{63}$ The Constitution prohibits prosecution for a capital or otherwise infamous crime except upon indictment of a grand jury, and expressly exempts "cases arising in the land or naval forces." U.S. ConsT. amend. V.

The right to jury trial provided for in the sixth amendment by implication does not apply to the military since that right generally applies only to those entitled to the indictment provisions of the fifth amendment. Ex parte Milligan, 7x U.S. (4 Wall.) 2 (1866).

"In Reid v. Covert, 354 U.S. I, 37 (1956), Mr. Justice Black pointed out that, "As yet, it has not been clearly settled to what extent the Bill of Rights and other protective parts of the Constitution apply to military trials." See Ex parte Quirin, 3I7 U.S. I (I 942); Creary v. Weeks, 259 U.S. 336 (1922). In Ex parte Milligan, supra note 53, at 138, Chief Justice Chase stated, "We think, therefore, that the power of Congress, in the government of the land and naval forces and of the militia, is not at all affected by the fifth or any other amendment." For an exposition of the view that safeguards of the Bill of Rights have no application to military courts-martial, see Wiener, CourtsMartial and the Bill of Rights: The Original Practice (pts. I-2), 72 HARv. L. REv. I, 266 ( 1958). But of., Burns v. Wilson, 346 U.S. I37 (1953), wherein the Court expressed the view that all tribunals and all judges-military tribunals included-are charged with the preservation of constitutional rights of an accused; Day v. Wilson, 247 F.2d 660 (2d Cir. 1957); Dickenson v. Davis, 245 F.2d 3i 7 (Ioth Cir. 1957); Michaelson v. Herren, 242 F.2d 693 (2d Cir. 1957); Dixon v. United States, 237 F.2d 509 (I oth Cir. 1956); Burns v. Lovett, 202 F.2d 335340 (D.C. Cir. 1952). See Henderson, Courts-Martial and the Constitution: The Original Understanding, $7 \mathrm{x}$ HaRv. L. Rev. 293 (1957); SNedeker, Military Justice Under the Uniform CODE 445 ( 1953 ).

${ }^{86}$ The remarks by the Court of Military Appeals in United States v. Clay, I U.S.C.M.A. 74, 77, I C.M.R. 74, 77 ( $195 \mathrm{I}$ ), to the effect that principles of military justice are not based on the rights and privileges of the Constitution but rather, on the laws enacted by Congress, would indicate that constitutional guarantees as such have little applicability in the military sphere. Until the untimely death of Judge Brossman in December, 1955, this view had been embraced by the majority of the court. United States v. Deain, 5 U.S.C.M.A. 44, 53, 56, I7 C.M.R. 44, 53, 56 (1954) (concurring opinion); United States v. Welch, I U.S.C.M.A. 402, 408, 3 C.B.R. 136, 142 (1952) (dictum). However, with the appointment of Judge Ferguson, it has become clear that the majority of the court now subscribes to the view that constitutional guarantees do indeed apply to servicemen. In United States v. Ivory, 9 U.S.C.M.A. $516,523,26$ C.M.R. 296, 303 ( 1958 ) (concurring opinion), Judge Ferguson stated: "It is my considered opinion it cannot be contended that a man who joins our armed forces and offers his person to 
the desirability of "placing military justice on the same plane as civilian justice, ${ }^{\text {"56 }}$ and has endeavored to achieve that aim by securing to the accused rights and privileges identical to those granted civilians by the Constitution and federal statutes.

The court has sometimes indicated, however, that, while these rights and privileges parallel those accorded civilian defendants, they are bottomed on a judicially constructed "military due process," derived from the laws enacted by Congress rather than from the guarantees contained in the Constitution. ${ }^{58}$ The dichotomy is apparently based upon the premise that the military and civilian communities are separate and distinct ${ }^{59}$ and that each is confronted with its own peculiar problems in the dispensation of justice. This idea found expression in Burns v.

fight for the Constitution and the institutions predicated thereon forfeits the fundamental guarantees granted to citizens generally, except those excluded by the Constitution expressly or by necessary implication, which this document affords the accused." Similarly, Chief Judge Quinn has, since 1953, contended that every serviceman is entitled to the same rights, privileges, and guarantees as other citizens, except where specifically proscribed by the Constitution. United States v. Burney, 6 U.S.C.M.A. 776, 803, 21 C.M.R. 98, 125 (1956); United States v. Barnaby, 5 U.S.C.M.A. 63, 65, 17 C.M.R. 63, 65, (1954) (dissenting opinion); United States v. Williamson, 4 U.S.C.M.A. 320, 331, 15 C.M.R. 320,33 I (1954) (dissenting opinion). In United States v. Ivory, 9 U.S.C.M.A. 516, 522, 26 C.M.R. 296, 302 (1958) (concurring opinion) he avers that, ". . a question of double jeopardy is not answered simply in terms of the provisions of Article 44, Uniform Code of Military Justice," since the accused is entitled to all the constitutional guarantees not excluded expressly or by necessary implication.

${ }^{60}$ United States v. Sutton, supra note 55, at 223, I I C.M.R. 223 (1953); United State v. Clay, I U.S.C.M.A. 74, 77, I C.M.R. 74, 77 (1951). Accord, C.M. 38976, Washington, 22 C.M.R. 346, 349 (1956).

${ }^{57}$ In N.C.M. 372 , Gibbs, I8 C.M.R. 379, 381 (1954), the Board of Review, quoting Wurfel, Military Due Process: What Is It?, 6 VAND. L. REv. 251, 286 (1953), defined military due process as follows: "Military due process is not jurisdictional, it is not constitutional due process, it is not violated by a cumulation of nonprejudicial error, it is not general prejudice and it has not once been mentioned by Congress in the Uniform Code of Military Justice. By process of elimination then, any violation of a provision of the Uniform Code of Military Justice resulting in error which the court finds materially prejudiced the substantial rights of an accused constitutes a want of military due process. Conversely, any military tribunal action, within its jurisdiction, supported by 'some substantial evidence' in which the court finds no crror materially prcjudicial to the substantial rights of the accused is one complyiug with military due process." See also, United States v. Sutton, 3 U.S.C.M.A. 220 , II C.M.R. 220 (1953).

${ }^{58}$ United States v. Clay, 1 U.S.C.M.A. 74, I C.M.R. 74 (1951); United States v. Sutton, supra note 57 .

69 The fact that the administration of military justice presents problems differing from those confronting civil courts is pointed out by the court in United States v. Voorhees, 4 U.S.C.M.A. 509, 531, 16 C.M.R. 83, ro5 (1954). In that case, the court noted that certain concepts, while "workable, and perhaps even highly desirable in the civilian community ... could be extremely dangerous ... or even fatal" in the military sphere. 
Wilson, ${ }^{60}$ where the United States Supreme Court, recognizing that there is a marked distinction between the spheres of civil and military law, announced that basic rights of the serviceman "must perforce be conditioned to meet certain overriding demands of discipline and duty ....."11

Even so staunch a critic of military courts-martial as Mr. Justice Black has acknowledged that important differences exist between the two legal systems. In Reid v. Covert, ${ }^{62} \mathrm{Mr}$. Justice Black, although speaking in a quite different context, stated: ${ }^{83}$

... 'it still remains true that military tribunals have not been and probably never can be constituted in such way that they can lave the same kind of qualifications that the Constitution has deemed essential to fair trials of civilians in federal courts.' In part this is attributable to the inherent differences in values and attitudes that separate the military establislıment from civilian society. In the military, by necessity, emphasis must be placed on the security and order of the group rather than on the value and integrity of the indjvidual.

As regards the fourth amendment, the Court of Military Appeals has in the past expressed the view that, under the Uniform Code of Military Justice, military personnel have no substantive right to be secure from unreasonable search and seizure, but are protected merely by a rule of adjective military law. ${ }^{64}$ Indeed, some tribunals have asserted that the immunity from unreasonable search and seizure, as guaranteed by the fourth amendment, does not extend to military premises. ${ }^{65}$

According to this view, the provisions of the Manual for Courts-

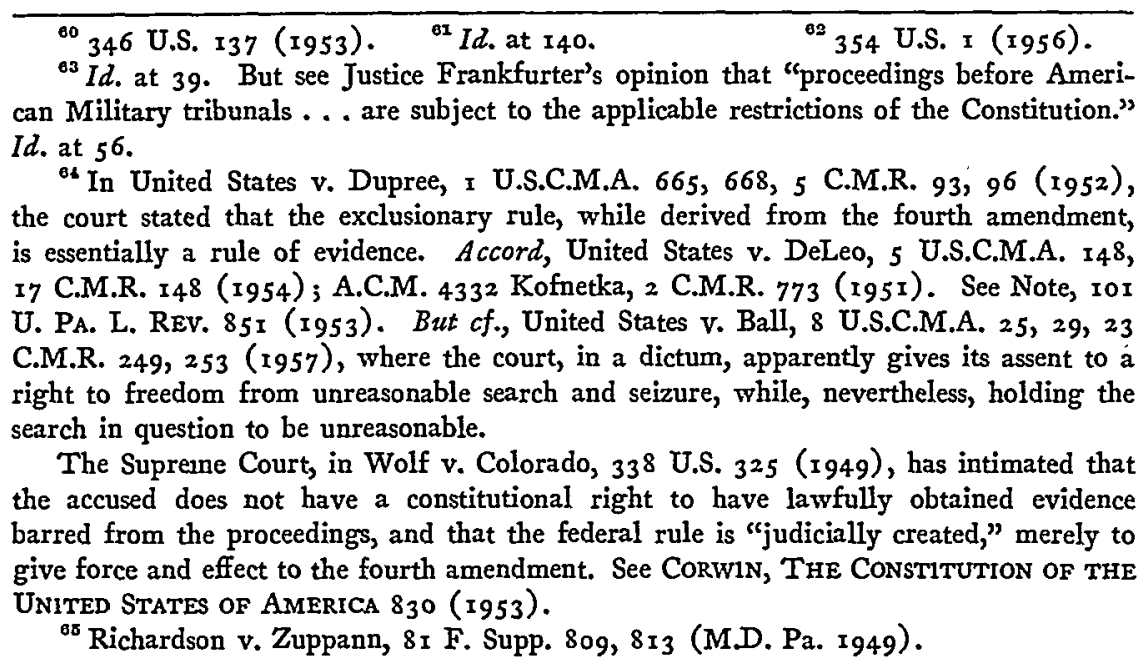


Martial which pertain to immunity from unreasonable search, are only the promulgation by the President of an exclusionary rule of evidence, rather than the affirmation of a constitutional right. If this is so, the President-or at most the President and the Congress-could change the rule of exclusion at his, or their, discretion to permit searches that are presently forbidden by the Manual. ${ }^{63}$ Apparently, the Court of Military Appeals is now taking a quite contrary position and asserting the existence and inviolability of a serviceman's right against unreasonable searches and seizures. In so doing, the court not only disregards its own precedent but also directly contradicts what has long been regarded as within the presidential prerogative. ${ }^{67}$

\section{$\mathrm{V}$}

\section{ConcLusion}

The Constitution expressly entrusts Congress with the power to enact rules for the government and regulation of the armed forces, ${ }^{08}$ and exempts the administration of military justice from the provisions of the judiciary article. ${ }^{09}$ Apparently the constitutional draftsmen recognized that acute considerations of order and discipline required other laws and modes of trial for service personnel than those of the common law, and that certain fundamental rights, such as that of trial by jury, necessarily had to be compromised if an effective military organization was to be maintained.

In attempting to accord to a serviceman every constitutional guaran-

\footnotetext{
${ }^{\circ 0}$ The Constitution confers power upon the Congress, "To make Rules for the Government and Regulation of the land and naval Forces." U.S. CoNST. art. I, § 8 . Except as otherwise restricted by statute, the Constitution apparently confers plenary powver on the President to make regulations for the government of the armed forces. As to the President's constitutional source of authority, see Kurtz v. Moffitt, II 5 U.S. 487,503 (1885); United States v. Eliason, 4r U.S. (16 Pet.) 29r, 301 (1842). As to statutory authority, see ro U.S.C. \$6012 (1958); 10 U.S.C. \$8061 (1958); 10 U.S.C. $\$ 306 \mathrm{r}(1958)$.

${ }^{e r}$ For an excellent exposition on usurpation of Presidential prerogative by the Court of Military Appeals, see Fratcher, Presidential Power to Regulate Military Justice: A Critical Study of Decisions of the Court of Military Appeals, 34 N.Y.U.L. REv. 86x (1959).

${ }^{68}$ See note 66 supra.

${ }^{19}$ Military tribunals are not courts in the sense of the judiciary article. Ex parte Quirin, 317 U.S. 1, 39, (1942); Grafton v. United States, 206 U.S. 333 (1907); In re Vidal, I79 U.S. 126, 127 (1900); Runkle v. United States, 122 U.S. 543 (1886); $E x$ parte Vallandigham, 68 U.S. (I Wall.) 243 ( 1863 ) (military commission). The authority to provide military court-martial proceedings is independent of the power conferred by article III, which defines the judicial power of the United States and is grounded rather on article I, $\S 8$ (referring to legislative war powers) and on article II, $\S_{2}$ (referring to the President as Commander-in-Chief).
} 
tee that his civilian brethren enjoy, the Court of Military Appeals is quite obviously striving for a congruence of civil and military justice. ${ }^{70}$ It should be recognized, however, that criminal law, in a civilian environment, is not intended to fulfill exactly the same role that military justice must play in governing the armed forces. The military mission may sometimes, by its urgency and import, necessarily preclude the attention to procedural detail that would be possible in a civilian setting. Moreover, to some extent, the administrators of military justice are limited in the institutions upon which they can draw for assistance. For instance, as to American forces overseas, no United States tribunal would be readily available to rule on the issuance of a search warrant, whereas in the United States this is not the case.

The primary function of the common-law system of criminal justice is to deter. Thus, the system is essentially negative; it seeks to restrain one's acting rather than to induce him to act. Military law, however, is more oriented to compelling positive action-to insuring the obedience to military order which is requisite to successful military operations. ${ }^{71}$

Assuming, arguendo, that equation of civilian and military justice is attainable, would it be desirable? Full inquiry into this complex problem lies beyond the scope of this discussion. It can be said with conviction, however, that unnecessary curtailment of the commanding officer's power to act in a situation as grave as that presented in the Brown ${ }^{72}$ case can render impotent the sanctions provided by the Uniform Code of Military Justice for the maintenance of order and discipline.

In the administration of military justice, it should be constantly borne in mind that the question is not only whether it provides "adequate safeguards for the accused" but "whether it provides adequate and effective systems of government and discipline to promote the mission of the armed services."ㄱ

\footnotetext{
${ }^{70}$ United States v. Burney, 6 U.S.C.M.A. 776, 21 C.M.R. 98 (1956); United States v. Voorhees, 4 U.S.C.M.A. 509, I6 C.M.R. 83 (1954).

${ }^{7 x}$ In those fields of civiliau criminal justice where the performance of a positive task is required, there is, occasionally, a relaxation of procedural safeguards similar to that of military law. For example, in the enforcement of tax regulations, contrary to the general rule prevailing in criminal law that the prosecutors must prove all the essential elements of the alleged offense beyond a reasonable doubt, the burden rests upon the accused to establish his innocence.

This might well indicate that the very nature of military law, with its mandatory functions, precludes the complete adoption by the Uniform Code of Military Justice of each and every safeguard considered to be essential to our civilian system of justice. See Fratcher, supra note 67.

72 10 U.S.C.M.A. 482,28 C.M.R. ${ }_{4} 8$ (1959).

${ }^{73}$ See Ward, UCMJ-Does It Work?, 6 VAND. L. REv. 186," I9I (1953).
} 